\title{
STRATEGI GURU PAI DALAM PENERAPAN BUDAYA RELIGIUS SEKOLAH DI SMA NEGERI 3 BATUSANGKAR
}

\author{
Yasmansyah \\ STAI al-Hikmah Pariangan Kabupaten Tanah Datar \\ Korespondensi: Jorong Padang Panjang Pariangan, Batusangkar, Sumatera Barat \\ e-mail: yasmansyah7@gmail.com
}

\begin{abstract}
2002
Abstract: The purpose of this study was to describe the activities, strategy undertaken as a form of religious culture school in SMANegeri 3 Batusangkar and supporting factors and penghambatn in the application of religious culture school in SMA Negeri 3 Batusangkar. This type of research used in this study is a qualitative research. Sources of data in this study is the Islamic Education teachers and principals and other data sources. Data collection techniques used were interviews, observation and documentation. Data-processing technique that is descriptive qualitative. Analysis of the data used, namely, data reduction, data presentation, drawing conclusions. While the validity of the data by triangulation technique that uses a variety of sources, such as interviews researcher with more than one respondent, observation and documentation. Strategy of teachers of Islamic education in the application of religious culture school that is embedded to the students well.Factors supporting the creation of religious culture school in SMANegeri 3 Batusangkar are internal factors (motivation) originating from within the students, the support of the assembly of teachers SMAN 3 Batusanggkar, their school programs such as FSI (Forum of Islamic Studies), the participation of alumni and the inclusion of some aspects of religious culture into the rules of conduct SMA Negeri 3 Batusangkar. While the inbibiting factor is the limited facilities and infrastructure, some students are still reluctant to implement some aspects of the religious culture of the school, existence of some aspects of the religious culture of the school that can not be required for students to do as well as the limitations of teachers to control students to his home and coupled with still the maximum parental controls to worship the child.
\end{abstract}

Keywords: Guru PAI dan Budaya Religius

\section{PENDAHULAN}

Pendidikan memiliki peran yang amat penting untuk menjamin perkembangan dan kelangsungan kehidupan bangsa yang bersangkutan. Untuk itu, pembangunan nasional di bidang pendidikan merupakan upaya mencerdaskan kehidupan bangsa dan meningkatkan kualitas manusia Indonesia, guna mewujudkan masyarakat yang maju, adil, dan makmur, serta memungkinkan setiap warga negaranya mengembangkan diri baik dalam aspek jasmaniah maupun rohaniah berdasarkan falsafah pancasila. (Abdul Majid, 2004: 5) 
Pendidikan diarahkan kepada pembentukan manusia yang berguna. Sedangkan pengajaran adalah salah satu alat atau usaha untuk membentuk manusia tersebut. Pendidikan bertujuan meningkatkan kualitas manusia Indonesia. Manusia Indonesia yang berkualitas ialah manusia yang beriman dan bertakwa kepada Tuhan Yang Maha Esa, berbudi pekerti luhur, berkepribadian, berdisiplin, bekerja keras, tangguh dan bertanggung jawab, mandiri, cerdas dan terampil serta sehat jasmani dan rohani.

Menurut Moh. Uzer yang juga dikutip oleh Mujtahid, mengungkapkan bahwa peserta didik adalah anggota masyarakat yang berusaha mengembangkan potensi diri melalui proses pembelajaran yang tersedia pada jalur, jenjang dan jenis pendidikan tertentu. Dalam pendidikan Islam, yang menjadi peserta didik bukan hanya anakanak, melainkan juga oarang dewasa yang masih berkembang, baik fisik maupun psikis. Hal itu sesuai dengan prinsip bahwa pendidikan Islam berakhir setelah seseorang meninggal dunia. Buktinya, orang yang hampir wafat masih dibimbing mengucapkan kalimat tauhid. (Mujtahid, 2011: 33-34) Jadi peserta didik merupakan pribadi yang menjalani proses pengembangan fitrahnya melalui pembelajaran untuk menjadi insan kamil.

Pendidikan Agama Islam diharapkan menghasilkan manusia yang selalu berupaya menyempurnakan iman, takwa, dan akhlak, serta aktif membangun peradaban dan keharmonisan kehidupan, khususnya dalam memajukan peradaban bangsa yang bermartabat. Akan tetapi jika dirinci lagi, tujuan mata pelajaran pendidikan agama Islam untuk sekolah menengah atas ialah:

1) Menumbuhkembangkan akidah melalui pemberian, pemupukan dan pengem- bangan pengetahuan, penghayatan, pengamalan, pembiasaan serta pengalaman peserta didik tentang agama Islam sehingga menjadi manusia muslim yang terus berkembang keimanan dan ketaqwaannya kepada Allah Swt.

2) Mewujudkan manusia Indonesia yang taat beragama dan berakhlak mulia yaitu manusia yang berpengetahuan, rajin beribadah, cerdas, produktif, jujur, adil, etis, berdisiplin, bertoleransi (tasamub), menjaga keharmonisan secara personal dan sosial serta mengembangkan budaya agama dalam komunitas sekolah. (Abdul Majid, 2004: 130)

Pekerjaan guru adalah mendidik. Mendidik itu merupakan suatu usaha yang amat kompleks, mengingat banyaknya kegiatan yang harus diantisipasi untuk membawa anak didik menjadi orang yang lebih dewasa. Kecakapan mendidik amat diperlukan agar tujuan pendidikan yang luas itu dapat dicapai semaksimal mungkin. Ini berarti kinerja guru harus benar-benar professional. (Baharuddin, 2009: 196)

Guru sebagai mediator dapat diartikan sebagai penengah dalam kegiatan belajar siswa. Misalnya menengahi atau memberikan jalan keluar kemacetan dalam kegiatan diskusi siswa. Namun sebagai mediator, guru harus menjadi perantara hubungan antar manusia. Dalam konteks ini guru harus terampil menggunakan pengetahuan tentang bagaimana berinteraksi dan berkomunikasi. Tujuannya agar guru dapat menciptakan secara maksimal kualitas lingkungan yang interaktif. Sehingga dalam hal ini ada beberapa kegiatan yang dapat dilakukan guru yakni mendorong berlangsungnya tingkah laku sosial yang baik serta menumbuhkan hubungan yang positif dengan siswa. (Ngainun Naim, 2009: 34) 
Sekolah menengah atas merupakan lembaga pendidikan yang di kelolah oleh kementerian pendidikan nasional, ini mempunyai predikat lembaga pendidikan archaic, dan menjadi pendidikan yang lahir langsung dari masyarakat dan juga dikelola oleh masyarakat (Wina Sanjaya, 2011: 145) Misi pendidikan Islam dalam hal ini pada lembaga pendidikan umum hampir sama dengan pondok pesantren haruslah mampu mewujudkan nilai-nilai ke-Islam-an di dalam pembentukan manusia Indonesia, yang dalam abad 21 ini akan bertemu antara tuntutan intelek dan tuntutan agama sehingga pendidikan Islam mampu menjadi pendidikan alternatif dikalangan masyarakat Indonesia secara umum. Menjadi pendidikan alternatif dalam kaitannya pendidikan pesantren ini mempunyai arti pesantren mampu berdiri sebagai lembaga pendidikan masyarakat dan menjadi penyeimbang antara pendidikan sekuler yang saat ini sedang dikembangkan (Asmaun Sahlan, 2010: 77)

Nurdin dalam bukunya juga menjelaskan bahwa betapapun bagusnya suatu kurikulum (official), tetapi hasilnya sangat tergantung pada apa yang dilakukan oleh guru dan juga siswa dalam kelas (actual). (Syafrudin Nurdin, 2002: 68) Bila dicermati kedua pernyataan di atas, maka keduanya menunjukkan bahwa berhasiltidaknya pelaksanaan kurikulum di sekolah sangat tergantung pada kinerja guru.

Strategi guru PAI agar seseorang terbiasa berbuat baik maka ia harus diajarkan sejak dini untuk berbuat baik sehingga sampai dewasa ia terbiasa berbuat baik. Kebiasaan tersebut seiring bergulirnya waktu bisa menjadi sebuah budaya. Berdasarkan observasi di SMA Negeri 3 Batusangkar guru PAI bersama dengan guru-guru yang lain serta kepala sekolah membuat perencanaan dari awal tentang kegiatan-kegiatan yang menjadi budaya sekolah yang dapat memberikan perobahan pada diri siswa: (Alfion,12 Desember 2015). Sedangkan budaya religius sekolah merupakan cara berpikir dan cara bertindak warga sekolah yang didasarkan atas nilai-nilai religius (keberagamaan) atau dengan kata lain, budaya religius sekolah pada hakikatnya adalah terwujudnya nilai-nilai ajaran agama sebagai tradisi dalam berperilaku dan budaya organisasi yang diikuti oleh seluruh warga sekolah.

Dengan demikian dapat dipahami bahwa budaya religius merupakan suatu kebiasaan yang dilakukan oleh warga sekolah yang dicerminkan dalam bentuk sikap atau perilaku yang didasarkan atas ajaran agama Islam. Sehingga, lingkungan sekolah menjadi lingkungan yang kental dengan nilai-nilai agama Islam. Dengan teori yang sudah ada dari berbagai pendapat tentang strategi guru PAI di SMA Negeri 3 Batusangkar sudah dari awal berdiri menerapkan budaya religius sekolah serta kualitas PBM secara bertahap dapat dikembangkan, sesuai dengan konsep awal SMA Unggulan Tanah Datar dengan sistem Boarding School. Berdasarkan dari observasi yang penulis lakukan, penulis melihat bahwa budaya reigius sekolah sudah terbentuk sejak sekolah ini berdiri di SMA 3 Batusangkar. Kalau di lihat secara logika luar biasa program dan kinerja guru untuk menerapkan budaya religius sekolah, sebagai sekolah umum yang memiliki kegiatan kegiatan keagamaan yang tinggi, semuanya itu terlaksana dapat di ukur dari kinerja guru. Akan tetapi dalam penerapannya, budaya religious sekolah ini sangat berbeda dengan sekolah atau Madrasah yang lebih 
banyakmateri pembinaan budaya religius atau budi pekerti siswa. Sebab di sekolah agama atau madrasah dalam kesehariannya budaya religius sekolah hanya sebahagian yang paling sering dipraktekkan oleh siswa.

\section{LANDASANTEOR}

\section{Guru Pendidikan Agama Islam}

Dalam Undang-Undang RI Nomor 14 Tahun 2005 tentang guru dan dosen dalam pasal 1 ayat (1) disebutkan bahwa guru adalah pendidik profesional dengan tugas utama mendidik, mengajar, membimbing, mengarahkan, melatih, menilai, dan mengevaluasi peserta didik pada pendidikan anak usia dinijalur pendidikan formal, pendidikan dasar dan pendidikan menengah. (Depdiknas, 2003: 83)

Sedangkan pendidikan Agama Islam adalah usaha sadar untuk menyiapkan siswa dalam meyakini, memahami, menghayati dan mengamalkan agama Islam melalui kegiatan bimbingan, pengajaran dan latihan dengan memperhatikan tuntutan untuk menghormati agama lain dalam hubungan kerukunan antar umat beragama dalam masyarakat untuk mewujudkan persatuan nasional. (Muhaimin, 2004: 75-76)

Sedangkan menurut Mujtahid, menyatakan bahwa guru merupakan sosok yang mengemban tugas mengajar, mendidik dan membimbing. Sementara itu menurut Moh. Uzer yang juga dikutip oleh Mujtahid, mengungkapkan bahwa guru adalah jabatan atau profesi yang memerlukan keahlian khusus sebagai guru. Untuk itu diperlukan syarat-syarat tertentu, apalagi guru profesional yang harus memerlukan seluk beluk pendidikan dan pengajaran dengan berbagai ilmu pengetahuan lainnya yang perlu dibina dan dikembangkan melalui masa pendidikan tertentu atau pendidikan pra-jabatan. (Mujtahid, 2011: 33-34)

Dengan demikian guru merupakan orang yang berprofesi sebagai pendidik yang memiliki beberapa tugas utama seperti: mendidik, mengajar, membimbing, mengarahkan, melatih, menilai dan mengevaluasi peserta didik serta mempunyai tanggung jawab terhadap perkembangan peserta didik, baik dalam meningkatkan kecerdasan intelektual, spritual maupun perkembangan emosionalnya. Sedangkan pendidikan Agama Islam adalah usaha sadar untuk menyiapkan siswa dalam meyakini, memahami, menghayati dan mengamalkan agama Islam melalui kegiatan bimbingan, pengajaran dan latihan dengan memperhatikan tuntutan untuk menghormati agama lain dalam hubungan kerukunan antar umat beragama dalam masyarakat untuk mewujudkan persatuan nasional. (Muhaimin, 2004: 75-76)

Jadi yang dimaksud dengan guru pendidikan agama Islam di sini ialah: seorang pendidik yang mempunyai tugas untuk mengajarkan materi tentang ajaran Islam kepada peserta didik sehingga mereka mampu mengetahui, memahami, dan mengamalkannya dalam kehidupan seharihari. Baik melalui pemberian ilmu pengetahuan agama, membimbing, melatih, mengarahkan maupun dengan mengajarkan pada peserta didik.

\section{Budaya Religius}

Menurut Kamus Besar Bahasa Indonesia, budaya adalah pikiran akal budi, adat istiadat atau sesuatu yang sudah menjadi kebiasaan yang sukar diubah. (Departemen Pendidikan dan Kebudayaan, 2003: 199) Menurut Peterson dalam Marwan Saridjo menyatakan bahwa budaya 
adalah seperangkat norma, nilai, kepercayaan dan tradisi yang berlangsung dari waktu ke waktu. (Marwan Saridjo, 2009: 68) Sementara Religius menurut kamus Besar Bahasa Indonesia ialah berarti bersifat keagamaan, yang bersangkut paut dengan religi (agama) (Departemen Pendidikan dan Kebudayaan, 2003: 830)

Sedangkan budaya religius sekolah merupakan cara berpikir dan cara bertindak warga sekolah yang didasarkan atas nilainilai religius (keberagamaan). Atau dengan kata lain, budaya religius sekolah pada hakikatnya adalah terwujudnya nilai-nilai ajaran agama sebagai tradisi dalam berperilaku dan budaya organisasi yang diikuti oleh seluruh warga sekolah. (Asmaun Sahlan, 2010: 75-76)

Dengan demikian dapat dipahami bahwa budaya religius merupakan suatu kebiasaan yang dilakukan oleh warga sekolah yang dicerminkan dalam bentuk sikap atau perilaku yang didasarkan atas ajaran agama Islam. Sehingga, lingkungan sekolah menjadi lingkungan yang kental dengan nilai-nilai agama Islam.

\section{METODE PENEUTAN}

Jenis penelitian yang penulis gunakan ialah field research (penelitian lapangan). Penelitian lapangan merupakan penelitian untuk menemukan secara spesifik tentang apa yang sedang terjadi ditengah-tengah masyarakat. Pada prinsipnya penelitian lapangan bertujuan untuk memecahkan masalah-masalah praktis dalam masyarakat. (Mardalis, 2003: 28) Adapun yang penulis maksud di sini ialah suatu penelitian yang bertujuan untuk mengungkapkan fenomena atau gejala sosial yang terjadi di SMA Negeri 3 Batusangkar khususnya tentang upaya guru PAI dalam menciptakan budaya religius sekolah di SMA Negei 3 Batusangkar sebagaimana adanya. Adapun metode penelitian yang penulis gunakan ialah metode penelitian deskriptif dengan menggunakan pendekatan kualitatif.

Instrumen dalam penelitian ini adalah peneliti sendiri yang menjadi instrumen kunci atau utama yang mengumpulkan data berdasarkan kriteria - kriteria yang dipahami. Instrumen pendukung pada penelitian ini adalah mengunakan pedoman observasi dan pedoman wawancara serta alat lainnya. Sumber data dalam penelitian ini ada 4 orang dengan menggunakan teknik pengumpulan data yaitu: observasi, wawancara dan dokumentasi.

Data yang diperoleh di lapangan dianalisis dengan menggunakan model analisis data kualitatif menurut Miles dan Huberman yang dilakukan secara interaktif melalui proses data reduction, data display, dan verificatipan (Sugiyono, 2007: 147). Yakni analisis data dimulai sejak pengumpulan data smapai seluruh data terkumpul dengan langkah-langkah berikut: reduksi data, penyajian data, dan verification.

\section{HASIL DANPEMBAHASAN}

\section{Kegiatan-Kegiatan yang Dilakukan Guru PAI dalam Penerapan Budaya Religius Sekolah}

Budaya sekolah adalah nilai-nilai dominan yang didukung oleh sekolah atau falsafah yang menuntun kebijakan sekolah terhadap semua unsur dan komponen sekolah termasuk stakeholders pendidikan, seperti cara melaksanakan pekerjaan di sekolah serta asumsi atau kepercayaan dasar yang dianut oleh personil sekolah. Budaya sekolah merujuk pada suatu sistem nilai, 
kepercayaan dan norma-norma yang diterima secara bersama, serta dilaksanakan dengan penuh kesadaran sebagai perilaku alami, yang dibentuk oleh lingkungan yang menciptakan pemahaman yang sama diantara seluruh unsur dan personil sekolah baik itu kepala sekolah, guru, staf, siswa dan jika perlu membentuk opini masyarakat yang sama dengan sekolah.

Guru PAI SMA Negeri 3 Batusangkar dalam penerapan budaya religius sekolah menyadari aspek penting dari kualitas SDM karena kualitas SDM bangsa menentukan kemajuan suatu bangsa. Budaya religius sekolah yang berkualitas perlu dibentuk dan dibina sejak dini serta berkelanjutan. Kagagalan penenaman kepribadian yang baik di usia dini akan membentuk pribadi yang bermasalah dimasa dewasa kelak.

Strategi guru PAI SMA Negeri 3 Batusangkar bahwa mulai berdiri sekolah SMA Negeri 3 Batusangkar sudah memulai untuk menerapkan budaya religius sekolah sebagai ciri khas sekolah unggulan, melalui kegiatan kegiatan yang sudah di rancang bersama membentuk siswa yang berkarakter, berakhlak mulia dan budaya religius sekolah (Alfion: 22 Juli 2017) merupakan kegiatan sekolah yang terdiri dari kegiatan keagamaan yang sifatnya membimbing kepribadian siswa. Berdasarkan data yang telah didapat, budaya religius ada berbentuk kegiatan ke agamaan yang rutin dilaksanakan di SMA Negeri 3 Batusangkar.

Budaya religius tersebut merupakan hasil dari penciptaan budaya religius di lingkungan sekolah, kemudian menjadi kebutuhan bagi setiap guru untuk menularkan kepada siswa, sehingga terbentuklah situasi yang bernuasa budaya religius sekolah di SMA Negeri 3 Batusangkar.
Adapun beberapa strategi guru PAI SMA Negeri 3 Batusangkar dalam bentuk kegiatan yang dilaksanakan sebagai wujud budaya religius sekolah di sekolah tersebut adalah sebagai berikut:

a. Budaya Senyum Salam dan Sapa (3S)

Strategi guru PAI di SMA Negeri 3 Batusangkar dalam penerapan budaya religius sekolah melalui Budaya 3S (senyum, salam, sapa) di sekolah merupakan cita-cita iklim dan budaya di lingkungan sekolah. Namun, hal tersebut tidak selalu sesuai dengan harapan sekolah yang memajang tulisan tersebut. Tidak semua warga sekolah mengindahkan keinginan tersebut.Tidak hanya siswa, bahkan guru maupun pegawai juga mengacukan budaya tersebut. Sehingga lambat laun budaya 3S pun akan luntur. Dalam pembentukan karakter siswa melalui penerapan pendidikan berbasis karakter khususnya dengan membudayakan budaya $3 \mathrm{~S}$ ini di sekolah, diharapkan seluruh pihak-pihak terkait seperti orang tua, guru, maupun warga sekitar turut berpartisispasi untuk membantu dan mendukung implementasi budaya 3S ini, sehingga karakter siswa dapat diarahkan dan dibentuk kearah yang lebih baik lagi.

Lingkungan di SMA Negeri 3 Batusangkar perlu diatur sedemikian rupa sehingga memberikan efek positif bagi peserta didik. Salah satunya dengan menciptakan lingkungan sekolah yang sarat dengan nilai-nilai ajaran Islam atau berbudaya religius. Dari segala potensi yang ada, SMA Negeri 3 Batusangkar telah berupaya untuk menciptakan budaya religius di sekolah tersebut terutama dari guru-guru PAI itu sendiri. Pengembangan budaya sekolah harus senantiasa sejalan dengan visi, misi dan tujuan sekolah. Fungsi visi, misi, dan tujuan sekolah adalah 
mengarahkan pengembangan budaya sekolah. Visi tentang keunggulan mutu misalnya, harus disertai dengan programprogram yang nyata mengenai penciptaan budaya sekolah.Bahwa penerapan budaya religius di SMA Negeri 3 Batusangkar sudah menjadi program sekolah dari awal berdirinya, budaya religius yang ada di SMA Negeri 3 Batusangkar bermula dari penciptaan suasana religius secara istiqamah. Penciptaan suasana religius dapat dilakuklan dengan kegiatan kegiatan keagamaan yang rutin. (Alfion, 27 Juli 2017)

\section{b. Berdoa Sebelum Belajar}

Pentingnya do'a selain sebagai ibadah dalam rangka berdzikir sekaligus bermunajat kepada Allah SWT, do'a dapat juga menjadi autosugesti bagi setiap siswa-siswi kita untuk belajar dengan lebih sungguhsungguh tentunya dalam hal-hal yang diridloi-Nya, dan insya Allah segala aktivitas belajar-mengajar pada hari itu dan seterusnya dinilai Allah SWT sebagai amal kebaikan yakni digolongkan dalam umat penuntut ilmu yang selalu berdzikir kepadaNya. Sebagai strategi guru PAI SMA Negeri 3 Batusangkar melakukan kegiatan rutin adalah kegiatan yang dilakukan secara reguler dan terus menerus di sekolah. Tujuannya untuk membiasakan siswa melakukan sesuatu dengan baik. Kegiatan pembiasaan yang termasuk kegiatan rutin adalah berdoa sebelum memulai kegiatan belajar. Kegiatan berdoa sebelum belajar ini bertujuan untuk membiasakan peserta didik berdoa sebelum memulai belajar dilaksanakan setiap pagi secara terpusat dari ruang belajar.

c. Asmaul Husna
Kegiatan ini bertujuan membiasakan peserta didik untuk berdzikir, mengingat nama-nama Allah. Kegiatan ini dilaksanakan secara terpusat dari ruang insformasi dengan petugas yang terjadwal.

Strategi yang di lakukan oleh guru PAI di SMA Negeri 3 Batusangkar dengan selalu pembiasaan berdoa sebelum dan akhir pelajaran. Semua guru bertanggung jawab penuhu untuk pembiasaan berdoa sebelum belajar. Karena diketahui aktivitas belajar ini bukan hal yang mudah. Perlu biaya, waktu dan kemauan yang tidak semua orang bisa memilikinya. Ada pula penghalangpenghalang lainnnya yang dapat membuat kita jauh dari keinginan untuk belajar. Dengan berdoa, maka akan banyak sekali hikmah yang akan diterima.

\section{d. Sholat Dhuha}

Setiap muslim hendaknya senantiasa mengingat Allah, baik ketika dikaruniai rezki yang melimpah maupun ketika menghadapi musibah. Salah satu cara terbaik yang dianjurkan Rasulullah adalah dengan melakukan sholat Dhuha. Orang yang rajin melaksanakan sholat Dhuha akan membuat keimanan dan ketaqwaannya semakin meningkat. Selain itu ia juga akan disayangi dan dianugrahkan rezki oleh Allah karena ia senantiasa meminta hanya kepada Allah. Disamping itu, hati dan pikirannya juga akan menjadi bersih sehingga terhindar dari hal-hal yang membuat ia terjerumus untuk melakukan dosa. Dalam penerapan shalat Dhuha terlebih dahulu guru PAI di SMA Negeri 3 Batusangkar memberikan penjelasan dan sosialisasi kepada seluruh siswa untuk memahami arti penting dari amalan shalat dhuhaha. Sehingga siswa SMA Negeri 3 Batusangkar dapat memahami dengan baik. 
Strategi guru PAI SMA Negeri 3 Batusangkar dalam penerapan budaya religius sekolah melalu shalat Dhuha, sholat Dzuhur berjamaah, budaya religius, tadarrus al-Qur'an memang telah terlaksana dengan baik. Bahwa para guru sendiri juga sering melaksanakan sholat Dhuha, Sholat Dzuhur berjamaah dan puasa Senin Kamis ini. (Nadiarlis: 4 agustus: 2017) Untuk sholat Dhuha ini umumnya siswa SMA Negeri 3 Batusangkar tidak lagi dilakukan pengontrolan secara ketat. Karena ini sifatnya lebih banyak panggilan hati. Akan tetapi bagi kelas $\mathrm{X}$ mereka wajib mengisi buku Agenda Sholatnya. Dalam buku Agenda Sholat tersebut ada beberapa kolom yang harus mereka isi. Kolom tersebut di antaranya memuat hal-hal yakni pelaksanaan sholat fardhu, sholat sunnah; sholat sunat rawatib; Dhuha dan Tahajud, tadabur alqur'an, infak, puasa, membantu orang tua dan belajar. Selain itu ada juga kolom saran dan tanggapan baik dari orang tua maupun guru serta kolom paraf orang tua dan guru. Buku agenda sholat tersebut dievaluasi setiap satu kali dalam seminggu, namun biasanya diperiksa setiap hari Kamis. Bagi siswa yang enggan melaksanakan sholat Dhuha maka diberikan catatan pada agenda sholat siswa.

e. Sholat Dzuhur Berjamaah

Peran SMA Negeri 3 Batusangkar bukan hanya sebatas mendidik siswanya agar menjadi manusia yang pandai, tetapi SMA Negeri 3 Batusangkar juga mempunyai peran dalam membina karakter siswa agar mampu diterima dan membawa manfaat di lingkungan masyarakat. Sebagai salah satu sekolah favorit di Batusangkar tentunya pandangan orang lain terhadap sekolah bermacam-macam.
Sebagian besar masyarakat berpemikiran bahwa sekolah berlabel sekolah unggul itu pengetahuan tentang agamanya kurang, padahal sekarang ini sudah banyak yang mulai melaksanakan kegiatan keagamaan demi membina karakter siswasiswanya. Kegiatan shalat berjamaah yang dilaksana-kan sekolah ini bertujuan untuk mendidik siswa agar menjadi siswa yang memiliki akhlak terpuji dan terhindar dari akhlak yang tercela.

Guru PAI SMA Negeri 3 Batusangkar dalam penerapan budaya religius sekolah, untuk mewujudkan tujuan ini diperlukan usaha yang keras untuk menghimbau siswa agar mau melaksanakan shalat berjamaah. Terkadang kebanyakan siswa lebih senang shalat sendiri-sendiri di bandingkan dengan shalat berjamaah. Alasannya bermacammacam, ada yang mengatakan takut karena di jam terakhir akan ada ulangan dan belum belajar, adalagi mengatakan yang belum mengerjakan PR sehingga waktu yang seharusnya digunakan untuk shalat berjamaah digunakan untuk aktivitas yang lain. Padahal meninggalkan shalat berjamaah demi pekerjaan itu dilarang oleh Allah SWT. (Alfion, 8 Agustus 2017)

Guru PAI dalam penerapan budaya shlat berjemaah lansung menjadi imam dan peran utama dalam kegiatan sekolah yang satu ini tentunya sudah tak asing lagi bagi siswa dan guru SMA Negeri 3 Batusangkar. Setiap hari warga sekolah selalu melaksanakan sholat duha dan sholat dhuhur, sementara pada harti jumat warga sekolah juga melaksanakan sholat Jumat berjamaah di sekolah dengan mendatangkan khatib dari luar sekolah dengan berkoordinasi dengan para mubaligh. (Nadiarlis, 8 Agustus 2017)

f. Tadarrus al-Qur'an 
Sekolah adalah lembaga pendidikan formal yang melaksanakan pendidikan dan pengajaran dengan disengaja, teratur, terprogram, terencana serta terarah. Diantara kegiatan-kegiatan terprogram yang diselenggarakan oleh sekolah dalam rangka meningkatkan prestasi belajar siswa adalah dengan program kegiatan pembiasaan. Pendidikan merupakan suatu pilar yang dibutuhkan suatu bangsa untuk menjalankan pembangunan. Seiring dengan perkembangan ilmu pengetahuan dan teknologi, upaya pembenahan dan perbaikan di bidang pendidikan adalah suatu keharusan yang harus dilaksanakan agar suatu bangsa bisa lebih maju dan berkembang.

Guru PAI SMA Negeri 3 Batusangkar dalam penerapkan budaya religius sekolah melalui tadarrus al-Qur`an merupakan salah satu bentuk kegiatan yang dapat membentuk kepribadian siswa. Siswa diwajibkan membawa al-Qur`an setiap hari, karena membaca al-Qur’an bisa di lakukan sendiri dan bisa secara bersama-sama. Tadarrus al-Qur'an atau kegiatan membaca al-qur'an merupakan bentuk peribadatan yang diyakini dapat mendekatkan diri pada Allah. Selain itu juga dapat meningkatkan keimanan dan ketaqwaan yang berimplikasi pada sikap dan prilaku positif, dapat mengontrol diri serta istiqamah dalam beribadah.(Asmaun, $2010: 10$ )

Dengan demikian dapat disimpulkan bahwa kegiatan tadarrus al-Qur'an telah menjadi budaya di SMA Negeri 3 Batusangkar.Budaya tadarrus al-Qur'an ini dilakukan setelah siswa selesai membaca Asmaul Husna dan do'a bersama yakni membaca do'a sebelum belajar.Kegiatan tadarrus al-Qur'an ini dilakukan siswa dengan tenang dan tidak tergesa-gesa. Sedangkan bagi siswa perempuan yang sedang berhalangan maka ia diwajibkan untuk mendengarkan temannya membaca al-Qur'an. Kemudian setelah itu dilanjutkan dengan menjelaskan kandungan dari beberapa ayat yang dibaca siswa.

\section{g. Istighasah/Do'a Bersama}

Istighasah atau do'a bersama bertujuan untuk memohon bantuan dan pertolongan kepada Allah. Inti dari kegiatan ini ialah untuk medekatkan diri pada Allah. Jika hambaNya sudah dekat dengan sang penciptanya yakni Allah, maka Allah pun juga akan dekat dengan hambanya tersebut. Oleh karena itu, do'a merupakan cara untuk memohon petunjuk serta pertolongan kepada Allah. (Asmaun Sahlan, 2010: 121)

Strategi guru PAI dalam penerapan budaya sekolah melalui do'a bersama memang telah menjadi budaya religius sekolah di SMA Negeri 3 Batusangkar. Sebab kegiatan ini rutin mengadakan do'a bersama pada moment-moment khusus. Biasanya do'a bersama dilakukan saat hari terakhir Masa Orientasi Siswa (MOS) yang langsung dipimpin oleh kepala sekolah atau oleh guru PAI. Selain itu do'a bersama juga dilakukan ketika siswa kelas XII akan menghadapi ujian nasional. Di mana tujuannya agar siswa memiliki keimanan dan mental yang kuat untuk menghadapi ujian tersebut.

Di samping itu, do'a bersama juga biasa dilakukan saat upacara bendera dan saat sebelum belajar. Hal ini bertujuan selain untuk mendo'akan para pahlawan agar ditempatkan pada tempat yang layak juga bertujuan agar siswa selalu ingat kepada Allah. Dan menyerahkan segala urusan hanya kepada Allah. Sementara itu, bagi siswa yang non muslim mereka dipersilahkan untuk berdo'a sesuai dengan 
tuntunan ajaran agama mereka masingmasing. (Alfion, 15 Agustus: 2017)

\section{h. Puasa Senin dan Kamis}

Puasa Senin dan Kamis merupakan amalan sunnah yang dapat memberikan dampak positif terhadap pribadi orang yang mengamalkannya. Seseorang yang melaksanakan puasa pasti akan berusaha menjaga ibadahnya agar tidak rusak oleh perbuatan keji dan mungkar.Strategi guru PAI dalam penerapan budaya religius sekolah melalui puasa senin dan kamis ini sudah dilaksanakan, baik oleh sebagian guru maupun siswa SMA Negeri 3 Batusangkar. Amalan ini memang belum lagi menjadi budaya di SMA Negeri 3 Batusangkar. Sebab ini merupakan amalan sunnah yang lebih menekankan pada panggilan hati masing-masing. Sehingga memang tidak dipaksakan kepada siswa untuk melaksanakan puasa Senin dan Kamis. Namun, agar siswa terpanggil hatinya untuk melaksanakan puasa Senin dan Kamis maka saya terlebih dahulu yang memberikan contoh kepada siswa untuk melaksanakan puasa Senin dan Kamis. Kecuali jika ada halangan, misalnya kebetulan ada dinas keluar. (Asrul, 9 Agustus: 2017)

Dengan amalan puasa sunah Senin dan Kamis dapat membentuk kepribadian siswa yang ideal seperti menjaga pandangan dan pendengarannya dari hal-hal yang dilarang agama sehingga ia memiliki jiwa yang bersih, pikiran yang positif serta memiliki rasa sosial yang tinggi. Guru PAI di SMA Negeri 3 Batusangkar selalu mengingatkan kepada seluruh siswa untuk melaksanakan puasa Senin dan Kamis selain bernilai ibadah juga bisa menjadi upaya preventif seseorang agar tidak terjerumus pada prilaku-prilaku yang tidak berlandaskan pada ajaran Islam. Di sisi lain guru PAI menerapkan dengan pencerahan kepada siswa bahwa puasa bernilai tinggi, terhindar dari siksa api Neraka. Begitu istimewanya ibadah puasa di hadapan Allah SWT sehingga orang tersebut akan diberikan ganjaran surga di akhirat. Namun, Allah SWT belum cukup dengan memberikan surga kepada orang-orang yang berpuasa. Allah SWT juga akan menjauhkan api neraka dari orang yang berpuasa sejauhjauhnya.

Pimpinan SMA Negeri 3 Batusangkar bahwa budaya religius sekolah menginginkan semua warga sekolah melaksanakan kegiatan puasa Senin dan Kamis, bagi yang tidak berpuasa ia akan merasa malu kepada guru dan teman-teman, secara administrasi tidak ada sanksi yang diberikan oleh guru kepada siswa yang tidak berpuasa senin dan kamis. Akan tetapi dengan pembiasaan yang diberikan oleh guru PAI pada akhirnya siswa dan guru-guru telah banyak melakukan puasa Senin dan Kamis di SMA Negeri 3 Batusangkar. (Asrul, 12 Agustus 2017)

\section{Strategi Guru PAI dalam Menciptakan Budaya Religius Sekolah}

a. Penciptaan Suasana Religius

Mengenai strategi guru PAI dalam menciptakan budaya religius sekolah yang berkaitan dengan penciptaan suasana religius SMA Negeri 3 Batusangkar. Ada beberapa kegiatan yang dilakukan seperti berdo'a sebelum belajar, sholat Jum'at, mengadakan PHBI serta kegiatan TURBA Ramadhan. Do'a sebelum belajar dilaksanakan sebelum melulai proses belajar mengajar atau pada saat jam pertama. Sebelum do'a dimulai anggota kelas disiapkan terlebih

168 Jurnal al-Fikrah, Vol. VI, No. 2 Juli-Desember 2018 
dahulu oleh ketua kelas kemudian secara bersama-sama membaca Asmaul Husna dan baru dilanjutkan dengan do'a bersama. Sementara itu setiap hari Jum'at semua siswa jam 7.15 Wib sudah berbaris di halaman sekolah untuk acara muhadarah dan dihadiri oleh kepala sekolah dan guru guru yang ngajar setiap Jumat. Siswa laki-laki diwajibkan sholat Jum'at di Masjid komplek sekolah. Sedangkan yang menjadi khatib dan imamnya adalah guru PAI itu sendiri dan mendatang ustadz dari luar lingkungan sekolah. Dan pernah juga siswa yang disuruh untuk menjadi khatib. (Alfion,12 Agustus: 2017)

b. Internalisasi Nilai

Terkait dengan strategi guru dalam menciptakan budaya religius sekolah melalui penerapan internalisasi nilai, bahwa untuk menciptakan buadaya religius sekolah juga dilakukan dengan menginternalisasikan nilai-nilai ajaran agama pada siswa. Misalnya dengan memberikan nasehat-nasehat kepada siswa seperti cara menegur dan menghormati guru, karyawan sekolah maupun sesama siswa. Hal tersebut diaplikasikan dengan cara siswa diajak dan disuruh untuk membudayakan budaya 3S.

Guru PAI SMA Negeri 3 Batusangkar dalam penerapan budaya religius sekolah melalui internalisasi nilai dengan pemberian nasehat ini dilakukan setiap ada kesempatan untuk siswa. Misalnya saat bercengkrama dengan siswa, menjadi pembina upacara bendera, saat kegiatan mubasabah maupun ketika menjadi narasumber saat pembekalan MOS bagi siswa baru. Selain itu siswa juga dibekali keimanannya melalui penyampaian materi pembelajaran sehingga materi tersebut diharapkan tidak hanya sekedar menambah wawasan pengetahuan saja namun dapat diamalkan dalam kehidupannya sehari-hari. (Alfion, 28 Juli: 2017)

c. Keteladanan

Keteladanan adalah tindakan atau setiap sesuatu yang dapat ditiru atau diikuti oleh seseorang dari orang lain yang melakukakan atau mewujudkannya, sehingga orang yang di ikuti disebut dengan teladan. Namun keteladanan yang dimaksud di sini adalah keteladanan yang dapat dijadikan sebagai alat pendidikan Islam, yaitu keteladanan yang baik. Sehingga dapat didefinisikan bahwa metode keteladanan (uswah) adalah metode pendidikan yang diterapkan dengan cara memberi contoh-contoh (teladan) yang baik yang berupa prilaku nyata, khusunya ibadah dan akhlak.

Strategi yang di lakukan oleh guru PAI SMA Negeri 3 Batusangkar meneladani bagaimana siswa SMA Negeri 3 Batusangkar dapat mencontoh akhlak Rasulullah SAW dalam menjaga hubungannya dengan sesama muslim yang senantiasa berkasih sayang dan mempererat silaturrahmi atau ukhwah, dilain pihak Rasulullah SAW juga memperlihatkan betapa tidak boleh bekerja sama (menjalani hubungan kemitraan) yang didasarkan atas kekufuran. Bukan sebaliknya yang bekerja sama dengan orang-orang kafir dan bermusuhan dengan sesama muslim.

d. Pembiasaan 
Strategi guru PAI di SMA Negeri 3 Batusangkar menjadikan sekolah yang berbudaya religius maka guru PAI strategi penerapan budaya religius sekolah juga melakukan upaya pembiasaan pada siswa sebagai salah satu bentuk strategi dalam menciptakan budaya religius sekolah. Upaya pembiasaan ini dilakukan pada beberapa aspek kegiatan seperti: kegiatan sholat Dzuhur berjamaah, tadarrus al-Qur'an serta do'a bersama. Agar siswa terbiasa melaksanakan kegiatan sholat Dzuhur berjamaah maka sholat Dzuhur berjamaah ini dilakukan pada saat jam istirahat yang kedua yakni dalam rentang waktu 12:2012:45 WIB. Sholat Dzuhur berjamaah dilakukan di Masjid sekolah.Agar siswa tertib dalam melaksanakan sholat Dzuhur berjamaah maka setiap guru yang datang ke Masjid wajib mengatur serta mengontrol siswa sehingga sholat bisa dilakukan dengan tenang dan khusyuk.

Pembiasaan yang dilakukan oleh guru PAI di SMA Negeri 3 Batusangkar seperti dalam pelaksanaan sholat Dzuhur guru PAI lebih awal datang ke mesjid untuk mengatur jalannya pelaksanaan shalat berjemaah dimulai dengan dikumandangkannya adzan oleh siswa. Setelah itu dilanjutkan dengan Iqamat dan kemudian sholat Dzuhur berjamaah. Sementara itu, tadarrus al-Qur'an dibiasakan setiap sebelum akan memulai proses belajar mengajar yakni setelah siswa selesai membaca Asmaul Husna dan do'a bersama. Agar tadarrus alQur'an menjadi sebuah budaya maka siswa memang diwajibkan untuk membawa al-Qur'an setiap hari. Bagi yang lupa maka akan disuruh mencari alQur'an. Yang jelas mereka harus punya
al-Qur'an terutama saat kegiatan membaca al-Qur'an ini. Alhamdulillah kasus siswa yang tidak membawa al-Qur'an ini jarang ditemukan.Sebab rata-rata setiap kelas siswa membawa al-Qur'an. Sedangkan bagi siswa perempuan yang sedang berhalangan maka ia diwajibkan untuk mendengarkan temannya membaca al-Qur'an. (Alfion, 15 Agustuts: 2017)

\section{e. Pembudayaan}

Strategi guru PAI di SMA Negeri 3 Batusangkar tentang pembudayaan sekolah dikemukakan merupakan budaya sekolah adalah merupakan suatu pola asumsi-asumsi dasar, nilai-nilai, keyakinan-keyakinan, dan kebiasaan-kebiasaan yang dipegang bersama oleh seluruh warga sekolah, yang diyakini dan telah terbukti dapat dipergunakan untuk menghadapi berbagai problem dalam beradaptasi dengan lingkungan yang baru dan melakukan integrasi internal, sehingga pola nilai dan asumsi tersebut dapat diajarkan kepada anggota dan generasi baru agar mereka memiliki pandangan yang tepat bagaimana seharusnya mereka memahami, berpikir, merasakan dan bertindak menghadapi berbagai situasi dan lingkungan yang ada (Alfion, 10 Agustus: 2017). Membudayaan sekolah yang positif akan mendorong semua warga sekolah untuk bekerjasama yang didasarkan saling percaya, mengundang partisipasi seluruh warga, mendorong munculnya gagasan-gagasan baru, dan memberikan kesempatan untuk terlaksananya pembaharuan di sekolah yang semuanya ini bermuara pada pencapaian hasil terbaik. Budaya sekolah yang baik dapat menumbuhkan iklim yang mendorong semua warga sekolah untuk belajar, yaitu belajar bagaimana belajar dan belajar bersama. Akan tumbuh suatu iklim bahwa 
belajar adalah menyenangkan dan merupakan kebutuhan, bukan lagi keterpaksaan. Belajar yang muncul dari dorongn diri sendiri, intrinsic motivation, bukan karena tekanan dari luar dalam segala bentuknya. Akan tumbuh suatu semangat di kalangan warga sekoalah untuk senantiasa belajar tentang sesuatu yang memiliki nilainilai kebaikan.

\section{PENUTP}

\section{Kesimpulan}

Dari penelitian yang telah penulis lakukan tentang upaya guru PAI dalam menciptakan budaya religius sekolah di SMA Negeri 3 Batusangkar dapat disimpulkan. Kegiatan-kegiatan yang dilakukan di SMA Negeri 3 Batusangkar sebagai bentuk budaya religius sekolah di SMA Negeri 3 Batusangkar ialah budaya 3S (Senyum, Salam dan Sapa), saling hormat dan toleran, sholat Dhuha, sholat Dzuhur berjamaah, tadarrus al-Qur'an dan istighasah atau do'a bersama. Sementara itu, puasa Senin dan Kamis belum lagi menjadi budaya sekolah. Akan tetapi masih dalam tahap sosialisasi dan pengajakan agar siswa membudayakan puasa Senin dan Kamis. Strategi guru PAI dalam menciptakan budaya religius sekolah di SMA Negeri 3 Batusangkar ialah: penciptaan suasana religius, internalisasi nilai, keteladanan, pembiasaan, dan pembudayaan.

\section{Saran}

Sebagai sumbangan pemikiran bagi penulis tentang upaya guru PAI dalam menciptakan budaya religius sekolah di SMA Negeri 3 Batusangkar, maka peulis memberikan beberapa saran-saran yang barangkali dapat dipertimbangkan, agar penciptaan budaya religius sekolah di SMA Negeri 3 Batusangkar maupun di sekolahsekolah lainnya juga bisa terwujud dan berjalan maksimal. Agar siswa lebih termotivasi lagi dalam melakukan aspekaspek budaya religius sekolah maka pihak sekolah hendaknya membuat gebrakangebrakan positif. Misalnya dengan kegiatan pemilihan siswa teladan setiap akhir tahun sehingga hal ini diharapkan mampu mendorong siswa untuk melaksanakan aspekaspek budaya religius sekolah.Hendaknya lingkungan sekolah juga dipampangkan motto-motto, slogan, kata-kata bijak, kaligrafi dan sejenisnya yang berhubungan dengan icon budaya religius sekolah. Sehingga memberikan semangat bagi siswa untuk melaksanakan kegiatan-kegiatan yang merupakan bentuk dari budaya religius sekolah.

\section{KEPUSTAKAANACUN}

Abdul Majid, 2004. Pendidikan Agama Islam Berbasis Kompetensi, Konsep dan Implementasi Kurikulum 2004 (Bandung: Remaja Rosda Karya)

Asmaun Sahlan, 2010. Mewujudkan Budaya Religius di Sekolah, Upaya Mengembangkan PAI dari Teori ke Aksi. (Malang: UIN Maliki Press)

Baharuddin, 2009. Pendidikan dan Psikologi Perkembangan, (Jogjakarta: Ar-Ruzz Media)

Depdiknas, 2003. Undang-Undang Republik Indonesia No 14 Tabun 2005 tentang Guru dan Dosen (Bandung: Citra Umbara) 
Mardalis, 2003. Metode Penelitian Suatu Pendekatan Proposal, Jakarta: Bumi Aksara)

Marwan Saridjo, 2009. Mereka Bicara Pendidikan Islam Sebuah Bunga Rampai, (Jakarta: Raja Grafindo Persada)

Muhaimin, 2004. Paradigma Pendidikan Agama Islam; Upaya Mengefektifkan Pendidikan Agama Islam di Sekolah (Bandung: Remaja Rosda Karya)

Muhaimin, , 2004. Pradigma Pendidikan agama Islam, Upaya Mengefektikan Pendidikan Agama Islam di Sekolah (Bandung: Remaja Roda Karya)
Mujtahid, 2011. Pengembangan Profesi Guru (Malang; UIN Maliki Press)

Ngainun Naim, 2009. Menjadi Guru Yang Inspiratif; Memberdayakan dan Mengubah Jalan Hidup Siswa. (Yogyakarta: Pustaka Belajar)

Sugiyono, 2007. Metodologi Penelitian Pendidikan, (Bandung: Alfabeta)

Syafruddin Nurdin, 2016. Kurikulyum dan Pembelajaran, Jakarta: PT. RajaGranfindo Persada)

Wina Sanjaya, 2011. Pemebelajaran dalam Implementasi Kurikulum Berbasis Kompetensi. (Jakarta; Kencana Premedia Group) 